\title{
Clinico-Epidemiological Correlates of COVID-19 Cases - A Cross-Sectional Study from Assam, India
}

\author{
Anku Moni Saikia', Mehzabin Haider Hazarika², Ubedul Islam³ ${ }^{3}$ Kishore Kumar Ghosh", \\ Suddipta Kumar Bora ${ }^{5}$, Abdul Halim Sarkar ${ }^{6}$ \\ 1, 2, 4, 5, 6 Department of Community Medicine, Gauhati Medical College, Guwahati, Assam, India. \\ ${ }^{3}$ Department of Medicine, Gauhati Medical College and Hospital, Guwahati, Assam, India.
}

\section{ABSTRACT}

\section{BACKGROUND}

Considering the heavy toll taken by COVID- 19 pandemic, the understanding of the epidemiological parameters as well as various risk factors is crucial for future preparedness and tackling the pandemic in a more effective manner. We wanted to study the socio-demographic correlates of COVID -19 cases in Assam, India. Also to find the relationship of clinical status of COVID -19 cases with co- morbidities and with substance use.

\section{METHODS}

An institution-based cross-sectional study was undertaken from $1^{\text {st }}$ April 2020 to $31^{\text {st }}$ August 2020. Out of the total 12 COVID Care Centres / hospitals that had been established in Kamrup and Kamrup Metro districts of Assam, 6 were randomly selected. A total of 3000 patients were interviewed over telephone by using an android-based application; on or after discharge from the centres, while patient was put on mandatory quarantine. The patients were interviewed on various sociodemographic variables, co-morbidities and substance use behaviour. Categorical variables are expressed as percentages and the continuous variables are expressed as mean \pm standard deviation. t-test and chi-square test were used for continuous and categorical variables respectively.

\section{RESULTS}

Mean age of moderate and severe cases were 55.10 and 55.9 years respectively. Smoking and use of alcohol were significantly associated with severity of symptoms. Diabetes, hypertension and co-existing lung diseases were found to be associated with status of symptoms.

\section{CONCLUSIONS}

Epidemiological risk factors like age has to be relooked. Primary prevention on risk factors of non-communicable diseases proved to be crucial in prevention of severity of communicable pandemic like COVID-19. Further studies are required to enhance the knowledge on this aspect.

\section{KEY WORDS}

COVID-19, Substance Use, Diabetes, Hypertension, Lung Diseases, Status of Symptoms.
Corresponding Author:

Dr. Mehzabin Haider Hazarika, Assistant Professor,

Department of Community Medicine,

Gauhati Medical College,

Guwahati, Assam, India.

E-mail:drmehzabin@yahoo.com

DOI: $10.14260 / \mathrm{jemds} / 2021 / 797$

How to Cite This Article:

Saikia AM, Hazarika MH, Islam U, et al. Clinico-epidemiological correlates of COVID-19 cases - a cross-sectional study from Assam, India. J Evolution Med Dent Sci 2021;10(45):3947-3952, DOI: 10.14260/jemds/2021/797

Submission 22-11-2021,

Peer Review 29-11-2021,

Acceptance 22-12-2021,

Published 28-12-2021.

Copyright (c) 2021 Anku Moni Saikia et al. This is an open access article distributed under Creative Commons Attribution License [Attribution 4.0 International (CC BY 4.0)] 


\section{BACKGROUND}

COVID-19 is one of the worst forms of global health crisis faced by the entire world. It is wreaking havoc and has crippled the health care systems, even in most developed countries. Following the detection and reporting of pneumonia of unknown aetiology in Wuhan city of China, a novel coronavirus or SARS-nCoV2 was identified as the causative agent by the Chinese authorities on January 7, 2020. The outbreak was declared a Public Health Emergency of International Concern (PHEIC) by the World Health Organization (WHO) on January 30, 2020. Following this, WHO declared COVID-19, a global pandemic on March 11, 2020.

India found itself in the grip of this fast-spreading and fast-evolving virus too. With the medical student who had travelled from Wuhan, China, the then epicentre of COVID-19, to India on $30^{\text {th }}$ January 2020 , having tested positive, India recorded its first case. The spread of the virus in the country was initially confined to travel related cases and their contacts. Later, due to local transmission, cases increased exponentially without any known travel or contact history, expanding to almost all the states of India.

Assam, the gateway to North East India, experienced its first case on 31 ${ }^{\text {st }}$ March 2020, an attendee of the conference of Tablighi Jammat at Nizamuddin Markaz, Delhi. The Government of Assam responded to the pandemic before the occurrence of the first case, by initiating screening facilities at all entry points into the state. Although initial cases were confined to travel related or contact with positive cases, the community transmission started within a short period of time. The Government of Assam started mandatory institutional admission of the cases irrespective of the symptoms and intensive contact tracing for the contacts. The infrastructural upgradation and development was started with establishment of COVID Care Centres (CCC) or Hospitals along with the logistics management. Initially it was started in two districts-Kamrup and Kamrup (Metro) and subsequently expanded to other districts of the state.

The clinical presentations and epidemiological characteristics of patients with COVID-19 have been variable in different countries. The clinical presentation of COVID-19 infection varies from asymptomatic illness to severe respiratory distress and shock.1,2 Within the same country variations have been observed in different regions. It is of utmost importance to understand the disease dynamics by generating data of local population. Understanding the risk factors and epidemiological correlates will help to plan and refine preventive strategies to tackle this pandemic more efficiently. Hence, this study was planned to study the sociodemographic correlates of COVID -19 cases in Assam and also to find the relationship of clinical status with co- morbidities and substance use.

\section{METHODS}

An institution- based, cross- sectional study of the COVID -19 cases admitted in the selected COVID Care Centres (CCC) / Hospitals in Kamrup and Kamrup Metro districts was conducted from $1^{\text {st }}$ April 2020 to $31^{\text {st }}$ August 2020. Patients who gave consent were included in the study while patients who could not be contacted over phone were excluded. Out of the total 12 centres in Kamrup and Kamrup (Metro) Districts established during that period, $50 \%$ of them i.e. 6 were selected randomly using random number table. From each centre, the consecutive discharged cases were taken till the number reached 500. A total of 3000 cases were studied. Alternate day visits were made to the CCCs / Hospitals and prior day discharge data with phone numbers and available secondary data including the discharge sheets and clinical notes along with the investigation reports were collected. The cause of death in the hospital note was taken for the patients who died during the hospital stay or following discharge during the mandatory quarantine period. This is because of inability to collect the information physically considering the COVID -19 protocol. Skilled interviewers spoke to the patients over telephones during their post discharge mandatory quarantine period to obtain the required information. Predesigned and pretested interview schedule was used through an android-based application. Socio- demographic variables like age and sex and its relationship with status of symptoms were studied. Status of symptoms were classified as asymptomatic or symptomatic. The asymptomatic cases are laboratory confirmed cases (RT-PCR / RAT positive) not experiencing any symptoms. A symptomatic COVID-19 case is a laboratory confirmed case (RT-PCR / RAT positive) who has developed signs and symptoms compatible with COVID-19 virus infection. Symptomatic COVID-19 cases were categorized as mild, moderate and severe cases. Mild cases are those having upper respiratory tract symptoms (\& / or fever) without shortness of breath or hypoxia. Moderate cases are those having any of: 1 . Respiratory rate $\geq 24 / \mathrm{min}$, breathlessness 2. Sp02: $90 \%$ to $\leq 93 \%$ on room air. Severe cases are those having any of: 1 . Respiratory rate $>30 / \mathrm{min}$, breathlessness 2 . Sp02 $<90 \%$ on room air. These definitions are as per the Ministry of Health and Family Welfare, Government of India guidelines. Relationship of co-morbid conditions like diabetes mellitus, hypertension and lung diseases; and substance use were studied with the status of symptoms. While assessing the co-morbidities, previously known or diagnosed cases were considered irrespective of current status of the disease. However, hospital records, clinical notes on discharge sheet and investigation reports were considered for previously unknown or undiagnosed cases. Lung diseases which included chronic obstructive pulmonary disease (COPD), asthma, active pulmonary tuberculosis, lung cancer, bronchiectasis, were assessed based on history and clinical notes on the discharge sheets. The relationship of clinical status and substance use was analysed in terms of status of use, duration and frequency of use. In relation to substance use, only tobacco smoking and alcohol use were considered.

Permission from the Institutional Ethics Committee was obtained as per institutional norm. Verbal informed consent was taken and recorded with their permission.

\section{Statistical Analysis}

Backend data was collected as spread sheet and analysed in MS Excel and InStat Graph Pad. Categorical variables were expressed as percentages and the continuous variables were expressed as mean \pm standard deviation. $t$-test and chi-square 
test were used for continuous and categorical variables respectively.

$P$ value of less than 0.05 was considered statistically significant.

\section{RESULTS}

A total of 3000 cases were analysed under the present study. It was found that majority of the cases 2191 (73.1\%) were asymptomatic (Figure 1).

Among the symptomatic patients, majority reported fever $(81.8 \%)$ and cough $(62.48 \%)$. Shortness of breath $(22.51 \%)$, loss of appetite (35\%), myalgia (31\%), headache (28.78\%), loss of smell (9.96\%) and diarrhoea (2.58\%) were also reported in multiple response frequencies.

Table 1 depicts the mean age of cases as per gender. Mean age of males is lesser than the mean age of females and a statistically significant difference was observed. Mean age was found to be around 55 years in moderate and severe cases (Table 2).

Out of total 3000 patients, 12 patients died and the death rate was $0.4 \%$. The mean age of the dead patients was 55.91 years (SD 21.51). Out of the total 12 deaths, $58.33 \%$ were males and $41.67 \%$ were females.

While comparing the relationship between gender and status of symptoms, it was not seen to be statistically significant (Table 3).

Tobacco use and frequency of its use were found to be significantly associated with status of symptoms whereas duration was not found to be significantly associated with status of symptoms. Use of alcohol was found to be significantly associated with status of symptoms (Table 4).

Presence of co-morbidities - diabetes mellitus, hypertension and lung disease was found to be significantly associated with the status of symptoms (Table 5).

In univariate analysis, diabetes and hypertension were found to be significantly associated with death. However, while applying binary logistic regression, diabetes was only found to be highly significantly associated with death. (OR = 16 and $95 \% \mathrm{CI}$ is 4.01 to 63.9) (Table 6)

\begin{tabular}{|cccccc|}
\hline Gender & No. & $\begin{array}{c}\text { Mean Age } \\
\text { (in years) }\end{array}$ & $\begin{array}{c}\text { Standard } \\
\text { Deviation }\end{array}$ & $\begin{array}{c}\mathbf{9 5 \%} \\
\text { Confidence } \\
\text { Interval (CI) }\end{array}$ & $\begin{array}{c}\text { t test } \\
\text { P Value }\end{array}$ \\
Male (n=2149) & 2149 & 37.90 & 15.00 & $7.9-67.9$ & $\mathrm{t}=2.940$ \\
Female $(\mathrm{n}=851)$ & 851 & 39.76 & 17.1 & $5.6-74$ & $\mathrm{P}=0.0033$ \\
Total 3000 & $\mathbf{3 0 0 0}$ & $\mathbf{3 8 . 5}$ & $\mathbf{1 5 . 7}$ & $\mathbf{7 . 1 - 6 9 . 9}$ & \\
\hline \multicolumn{6}{|c|}{ Table 1. Relationship of Mean Age with Gender } \\
\hline
\end{tabular}

\begin{tabular}{|cccc|}
\hline Severity & No. (\%) & Mean Age (years) & Standard Deviation \\
Moderate & $51(6.3 \%)$ & 55.10 & 15.69 \\
Mild & $728(90 \%)$ & 39.59 & 15.05 \\
Total & $\mathbf{8 0 9}(\mathbf{1 0 0 \% )}$ & $\mathbf{4 1 . 1 7}$ & $\mathbf{1 5 . 7 7}$ \\
\hline \multicolumn{4}{|c|}{ Table 2. Mean Age of Mild, Moderate, and Severe Cases } \\
\hline
\end{tabular}

\begin{tabular}{|c|c|c|c|c|}
\hline Gender & $\begin{array}{l}\text { Asymptomatic } \\
\text { Number (\%) }\end{array}$ & $\begin{array}{c}\text { Symptomatic } \\
\text { Number (\%) }\end{array}$ & $\begin{array}{c}\text { Total } \\
\text { Number (\%) }\end{array}$ & $\begin{array}{c}\text { Odds Ratio } \\
\text { (OR) }\end{array}$ \\
\hline Males & $1578(72.02 \%)$ & $571(70.6 \%)$ & 2149 (71.6\%) & $\mathrm{OR}=1.07$ \\
\hline Females & $613(27.98 \%)$ & $238(29.4 \%)$ & $851(28.4 \%)$ & $\mathrm{C} \mathrm{I}=0.89-$ \\
\hline Total & $2191(100 \%)$ & $809(100 \%)$ & $3000(100 \%)$ & $\begin{array}{c}1.28 \\
\mathrm{P}=0.44\end{array}$ \\
\hline
\end{tabular}

\begin{tabular}{|c|c|c|c|c|c|}
\hline Use of Tobacce & $\begin{array}{c}\text { Asymptomatic } \\
\text { (\%) } \\
(n=2191) \\
\text { Number (\%) }\end{array}$ & $\%$ & $\begin{array}{c}\text { Symptomatic } \\
(\%) \\
(n=809) \\
\text { Number }(\%)\end{array}$ & $\%$ & $\begin{array}{l}\chi^{2} / \mathrm{df} / \\
\mathrm{P} \text { Value }\end{array}$ \\
\hline Yes (488) & $336(15.33)$ & 68.85 & 152 (18.79) & 31.15 & $\chi^{2}=5.17$ \\
\hline No (2512) & 1855 (84.67) & 73.84 & 657 (81. & 26.15 & $\begin{array}{c}\mathrm{df}=1 \\
\mathrm{P}-\text { Value }= \\
0.02\end{array}$ \\
\hline $\begin{array}{l}\text { Duration of } \\
\text { tobacco use }\end{array}$ & $(n=336)$ & & $(n=152)$ & & \multirow{4}{*}{$\begin{array}{c}\chi^{2}=0.05 \\
\mathrm{df}=1 \\
\mathrm{P}-\text { Value }= \\
0.83\end{array}$} \\
\hline$<1$ year (9) & $09(2$. & 100 & 00( & 0.0 & \\
\hline $1-5$ year $(161)$ & 1078 & 66.46 & & 33.54 & \\
\hline$>5$ year $(318)$ & 0( & 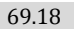 & 98( & 30.82 & \\
\hline $\begin{array}{l}\text { Frequency of } \\
\text { tobacco use }\end{array}$ & $(n=336)$ & & $(n=152)$ & & \multirow{5}{*}{$\begin{array}{c}\chi^{2}=29.76 \\
\mathrm{df}=2 \\
\text { P-Value } \\
<0.0001\end{array}$} \\
\hline Daily (272) & 165 & 6 & $107(70$ & 9.33 & \\
\hline $\begin{array}{l}\text { At least once a } \\
\text { week (136) }\end{array}$ & 97 (28.87\%) & 71.32 & $39(25.66 \%)$ & 28.68 & \\
\hline $\begin{array}{l}\text { At least once a } \\
\text { month (06) }\end{array}$ & 05 (1.49\%) & 83.33 & $01(0.66 \%)$ & 16.67 & \\
\hline Rarely (74) & 69 (20.54\%) & 3.24 & 05 (3.29\%) & 6.76 & \\
\hline Use of alcohol & $\mathrm{n}=219$ & & $n=80$ & & \multirow{3}{*}{$\begin{array}{c}\chi^{2}=7.72 \\
d f=1 \\
\text { P-Value }= \\
0.006\end{array}$} \\
\hline Yes (378) & 260 (11.87) & 67.18 & $127(15.70)$ & 32.81 & \\
\hline No (2613) & 1931 (88.13) & 73.90 & $682(84.30)$ & 26.10 & \\
\hline $\begin{array}{l}\text { Duration of } \\
\text { alcohol use }\end{array}$ & $(n=260)$ & & $(n=127)$ & & \multirow{4}{*}{$\begin{array}{c}\chi^{2}=0.86 \\
\mathrm{df}=2 \\
\text { P-Value }= \\
0.35\end{array}$} \\
\hline$<1$ year $(9)$ & 7 & 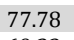 & & 22.22 & \\
\hline $1-5$ years $(130)$ & & & & 30.77 & \\
\hline$>5$ years $(248)$ & $163(62.69)$ & 65.72 & & 3427 & \\
\hline $\begin{array}{l}\text { Frequency of } \\
\text { alcohol use }\end{array}$ & $(n=260)$ & & $(n=127)$ & & \multirow{6}{*}{$\begin{array}{c}\chi^{2}=5.200 \\
\mathrm{df}=4 \\
\mathrm{P}-\text { Value }= \\
0.2674\end{array}$} \\
\hline Daily (17) & $10(3.8$ & 30.02 & $7(5$. & 41.18 & \\
\hline $\begin{array}{l}\text { Once in a week } \\
\text { (124) }\end{array}$ & 88 (33.84) & 70.96 & $36(28.35)$ & 29.03 & \\
\hline $\begin{array}{c}1-3 \text { times in a } \\
\text { week (29) }\end{array}$ & $19(7.30)$ & 65.51 & $10(7.87)$ & 34.48 & \\
\hline $\begin{array}{l}\text { Once in a month } \\
\text { (51) }\end{array}$ & 28 (10.77) & 54.90 & 23 (18.11) & 45.10 & \\
\hline Rarely (166) & $115(44.23)$ & 69.28 & $51(40.16)$ & 30.72 & \\
\hline
\end{tabular}

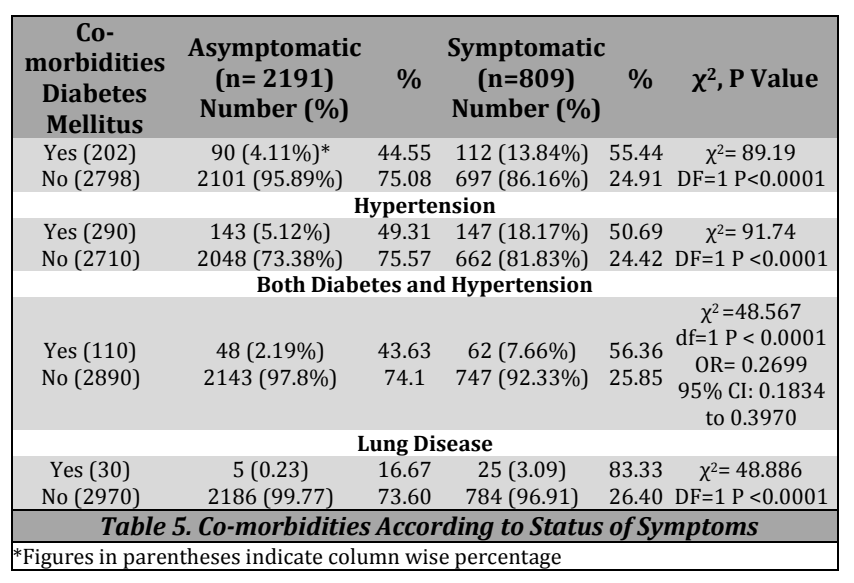

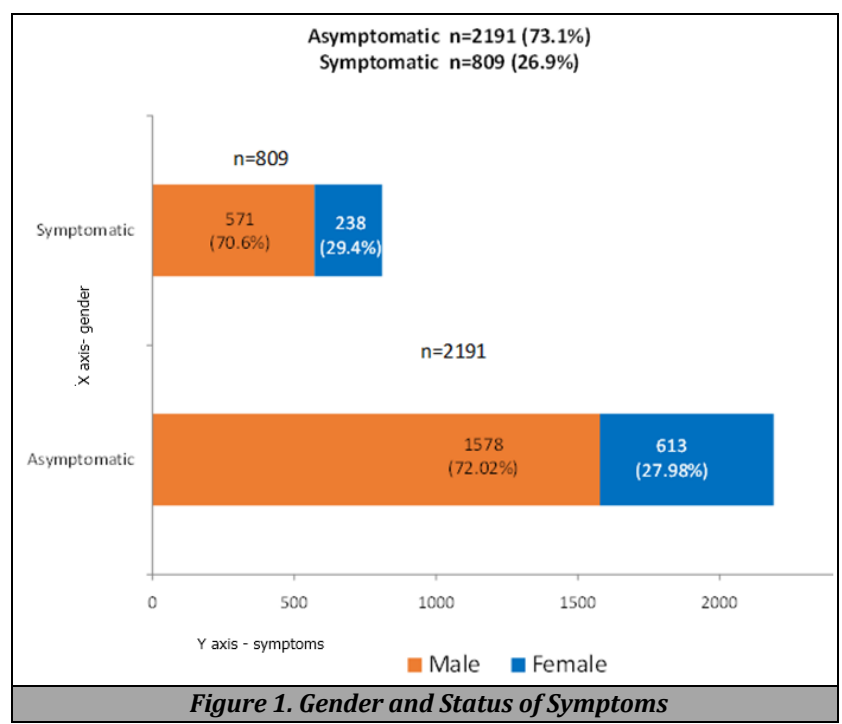




\begin{tabular}{|ccccc|}
\hline & P value & OR & \multicolumn{2}{c|}{ 95\% C.I. for OR } \\
Lower & Upper \\
\hline Hypertension & .539 & 1.547 & .385 & 6.221 \\
Diabetes mellitus & .000 & 16.020 & 4.012 & 63.976 \\
Constant & .000 & 23.337 & & \\
\hline $\begin{array}{c}\text { Table 6. Binary Logistic Regression Showing Relationship of Diabetes } \\
\text { and Hypertension with Death }\end{array}$ \\
\hline
\end{tabular}

\section{DISCUSSION}

The status of the disease along with socio-demographic characteristics, the relationship of co-morbidities and substance use behaviour with the severity of the disease for 3000 patients admitted in various COVID Care Centres / Hospitals in two districts of Assam were studied.

The overall mean age was found to be 38.5 years. A significant difference in the mean age between males and females was found. A study done in a tertiary care-centre in Haryana reported the mean age of the admitted patients as 40.1 years. ${ }^{3}$ The findings of the present study is in conformity with studies undertaken across the globe. ${ }^{4,5}$ In contrast to the present finding, a slightly higher mean age (45.8 years) among cases was reported by Tambe and his co-workers in a tertiary care hospital, Pune, Maharashtra. ${ }^{6}$

The mean age of 55 years in moderate and severe cases is a significant finding in the present study as this age needs to be considered as high risk group. In many studies, severity was more in the age group of 65 years and above.7,8,9 The variation in epidemiological distribution of the virus is obvious from this finding. The high-risk strategy in relation to age may need to be relooked considering the lower mean age in moderate and severe cases in the present study.

Increase in mortality with increase in age was reported by various studies across the globe ${ }^{10,11}$ which is in conformity to the present study though it contradicts results from another study where mortality showed no difference of susceptibility by age. ${ }^{12}$ The mean age of mortality (55.9 years) was found to be quite lower than a study done in Tamil Nadu where the mean age of mortality was found to be 62.5 years. ${ }^{13}$

The male preponderance which was observed in our study was found to be exhibited by various studies across the globe.3,4,6 This could be explained by more outdoor exposure and travel related risk behaviour among males even during the lockdown period. However, females were found to be more in a study done in the United States. ${ }^{8}$ The current finding of higher mean age in symptomatic rather than asymptomatic patients in both sexes is substantiated by other studies where prevalence of symptomatic were more in the older age group than the young population. ${ }^{9}$

While eliciting the relationship of tobacco smoking and alcohol use behaviour and status of COVID -19, the overall significant relationship between tobacco use, and its frequency with status of symptoms was in conformity with various studies done across the globe. 14,15,16,17,18 The results of the present study were un-adjusted for other factors which might impact the status of the disease. However, the metaanalysis done by Patanavanich and Glantzand, the systematic review done by Vardavas and Nikitara reported heterogeneity in the relationship in some studies; although smoking was found to increase the adverse outcome of COVID-19 in some studies. ${ }^{10,11}$ No significant association was reported between smoking and severity of the disease in many studies. ${ }^{19,20,21}$ No apparent increase in the risk of COVID-19 by active smoking was observed in another meta-analysis. ${ }^{22}$ The non-significant relationship between duration of smoking and status of symptom in the present study could be due to the fact that the effect of smoking is not only dependent on the duration, but also on the frequency and the amount taken. Inconclusive association of smoking and COVID-19 were observed in other studies done by different workers. ${ }^{23,24}$

Significant association between alcohol use and COVID-19 in the current study was in conformity with other work. ${ }^{25}$ The non-significant relationship between the duration and the frequency of alcohol use with severity of symptoms could be due to the inability to extract the precise information because of difficulty during the pandemic. Although several studies were found to be inconclusive regarding the association of substance use and COVID 19,23,24,26 the finding of the present study emphasized the role of primary prevention against tobacco and alcohol use in the prevention of risk of communicable diseases like COVID- 19.

A highly significant association of the severity of COVID 19 and the underlying co-morbidities - diabetes mellitus and hypertension was observed in our current study, which is similar with various other studies.17,19,27,28,29 In contrast to present finding, no significant association of COVID-19 and hypertension was found although diabetes and lung disease was found to be significantly associated. ${ }^{30}$ This difference is probably due to the variation of subclinical spectrum of hypertension and drugs used to control hypertension, some of which may lead to increased expression of ACE2. Although overall comparative analysis of COVID-19 patients with and without hypertension showed that hypertensive patients had greater disease severity and adverse progression than nonhypertensive patients, on multivariate analysis after adjusting for age and sex, did not show a significant correlation with increased COVID-19 disease severity or mortality. 19,31,32,33,34 The effect of anti-hypertensive drugs could not be studied in the present study, as many patients were newly diagnosed for hypertension during hospitalization for COVID-19.

Unfavourable health outcomes including increased risk of mortality is seen with hypertension and diabetes in several studies.35,36,37 Similar findings were also reflected in the present study, where logistic regression showed increased mortality in cases with diabetes. All cases of death had one or more co-morbidities.

It is well documented that diabetes increases the severity of COVID-19 disease. ${ }^{24,38}$ However the pathology is still not clear. The prevalence of diabetes was found to be higher in severe patients than in non-severe cases in many studies. ${ }^{24,38}$ Diabetes has the propensity to prolong the symptoms of COVID-19 and delay virus clearance as substantiated by some studies. ${ }^{38,39}$ Understanding the interaction between diabetes and COVID-19 could open a window for therapeutic measures, but there is paucity of data on this issue. 40

Although COPD prevalence in COVID-19 cases was low in a systematic review, ${ }^{41}$ COVID-19 infection was associated with substantial severity and mortality rates in COPD cases, which may be even as high as fourfold higher risk of developing severe COVID-19.19,41 The present finding of significant association between lung disease and COVID 19 was confirmed by several studies. ${ }^{31,38,42}$ 
The major limitation of the study was the inability to collect some information in details due to the emergency situation. Again information gathered in that time of the pandemic may have some limitations owing to the prevailing fear in the community. The study was conducted in the earlier part of the pandemic in the state, where the strategies on quarantine and isolation were different from the present strategies. With the changing scenario, the spectrum of disease also changed along with control strategies considering the case load and logistics, manpower and infrastructural availability.

\section{CONCLUSIONS}

The study reflects the variation in socio-demographic correlates like mean age in moderate and severe cases, which is lower than reported in other studies. So the age factor has to be relooked and redefined. Considering the role of diabetes mellitus, hypertension, smoking and alcohol use, there is an urgent need to re-emphasize on primary prevention of risk factors. Further studies are required in this regard to understand more about the disease epidemiology.

\section{Financial Support}

Srimanta Sankaradeva University of Health Sciences, Assam.

\section{Acknowledgement}

The Research Team gratefully acknowledges the contribution and support from 1. Shri Samir K Sinha, IAS, Principal Secretary to Chief Minister, Government of Assam. 2. Shri Anurag Goel, IAS, Principal Secretary, Health and Family Welfare Department, Government of Assam.3. Dr Lakshmanan S, IAS, Mission Director, National Health Mission, Assam. 4. Prof (Dr) Achyut C Baishya, Principal cum Chief Superintendent, Gauhati Medical College and Hospital, Guwahati, Assam.

Data sharing statement provided by the authors is available with the full text of this article at jemds.com.

Financial or other competing interests: Srimanta Sankaradeva University of Health Sciences, Assam..

Disclosure forms provided by the authors are available with the full text of this article at jemds.com.

\section{REFERENCES}

[1] Chen N, Zhou M, Dong X, et al. Epidemiological and clinical characteristics of 99 cases of 2019 novel coronavirus pneumonia in Wuhan, China: a descriptive study. Lancet 2020;395(10223):507-13.

[2] Chan JFW, Yuan S, Kok KH, et al. A familial cluster of pneumonia associated with the 2019 novel coronavirus indicating person-to-person transmission: a study of a family cluster. Lancet 2020;395(10223):514-23.

[3] Mohan A, Tiwari P, Bhatnagar S, et al. Clinicodemographic profile \& hospital outcomes of COVID-19 patients admitted at a tertiary care centre in north India. Indian J Med Res 2020;152(1 \& 2):61-9.
[4] Bhandari S, Shaktawat AS, Sharma R, et al. A preliminary clinico-epidemiological portrayal of COVID-19 pandemic at a premier medical institution of North India. Ann Thorac Med 2020;15(3):146-50.

[5] Mazumder A, Arora M, Bharadiya V, et al. SARS-CoV-2 epidemic in India: epidemiological features and in silico analysis of the effect of interventions. F1000Res 2020;9:315.

[6] Tambe MP, Parande MA, Tapare VS, et al. An epidemiological study of laboratory confirmed COVID-19 cases admitted in a tertiary care hospital of Pune, Maharashtra. Indian J Public Health 2020;64(Supplement):S183-7.

[7] Jin JM, Bai P, He W, et al. Gender differences in patients with COVID-19: focus on severity and mortality. Front Public Health 2020;8:152.

[8] Robilotti EV, Babady NE, Mead PA, et al. Determinants of COVID-19 disease severity in patients with cancer. Nat Med 2020;26(8):1218-23.

[9] Verity R, Okell LC, Dorigatti I, et al. Estimates of the severity of coronavirus disease 2019: a model-based analysis. Lancet Infect Dis 2020;20(6):669-77.

[10] Yanez ND, Weiss NS, Romand JA, et al. COVID-19 mortality risk for older men and women. BMC Public Health 2020;20(1):1742.

[11] Mahase E. Covid-19: death rate is $0.66 \%$ and increases with age, study estimates. BMJ 2020;369:m1327.

[12] Omori R, Matsuyama R, Nakata Y. The age distribution of mortality from novel coronavirus disease (COVID-19) suggests no large difference of susceptibility by age. Sci Rep 2020;10(1):16642.

[13] Asirvatham ES, Sarman CJ, Saravanamurthy SP, et al. Who is dying from COVID-19 and when? An Analysis of fatalities in Tamil Nadu, India. Clin Epidemiol Glob Health 2021;9:275-9.

[14] Patanavanich R, Glantz SA. Smoking is associated with COVID-19 progression: a meta-analysis. Nicotine Tob Res 2020;22(9):1653-6.

[15] Vardavas CI, Nikitara K. COVID-19 and smoking: a systematic review of the evidence. TobInduc Dis 2020;18:20.

[16] Guo FR. Active smoking is associated with severity of coronavirus disease 2019 (COVID-19 ): an update of a meta-analysis. Tob Induc Dis 2020;18:37.

[17] Pranata R, Soeroto AY, Huang I, et al. Effect of chronic obstructive pulmonary disease and smoking on the outcome of COVID-19. Int $\mathrm{J}$ Tuberc Lung Dis 2020;24(8):838-43.

[18] Zhao Q, Meng M, Kumar R, et al. The impact of COPD and smoking history on the severity of COVID-19: a systemic review and meta-analysis. J Med Virol 2020;92(10):1915-21.

[19] Zhou F, Yu T, Du R, et al. Clinical course and risk factors for mortality of adult inpatients with COVID-19 in Wuhan, China: a retrospective cohort study. Lancet 2020;395(10229):1054-62.

[20] Zhang JJ, Dong X, Cao YY, et al. Clinical characteristics of 140 patients infected with SARS-CoV-2 in Wuhan, China. Allergy 2020;75(7):1730-41.

[21] Huang C, Wang Y, Li X, et al. Clinical features of patients infected with 2019 novel coronavirus in Wuhan, China. Lancet 2020;395(10223):497-506. 
[22] Lippi G, Henry BM. Active smoking is not associated with severity of coronavirus disease 2019 (COVID-19). Eur J Intern Med 2020;75:107-8.

[23] Berlin I, Thomas D, Le Faou AL, et al. COVID-19 and smoking. Nicotine Tob Res 2020;22(9):1650-2.

[24] Guan WJ, Ni ZY, Hu Y, et al. Clinical characteristics of Coronavirus disease 2019 in China. N Engl J Med 2020;382(18):1708-20.

[25] Wang QQ, Kaelber DC, Xu R, et al. COVID-19 risk and outcomes in patients with substance use disorders: analyses from electronic health records in the United States. Mol Psychiatry 2021;26(1):40.

[26] Hamer M, Kivimäki M, Gale CR, et al. Lifestyle risk factors, inflammatory mechanisms, and COVID-19 hospitalization: a community-based cohort study of 387,109 adults in UK. Brain Behav Immun 2020;87:1847.

[27] Wang B, Li R, Lu Z, et al. Does comorbidity increase the risk of patients with COVID-19: evidence from metaanalysis. Aging (Albany NY) 2020;12(7):6049-57.

[28] Singh AK, Gupta R, Ghosh A, et al. Diabetes in COVID-19: prevalence, pathophysiology, prognosis and practical considerations. Diabetes Metab Syndr 2020;14(4):30310.

[29] Yang J, Zheng Y, Gou X, et al. Prevalence of comorbidities and its effects in patients infected with SARS-CoV-2: a systematic review and meta-analysis. Int J Infect Dis 2020;94:91-5.

[30] Iaccarino G, Grassi G, Borghi C, et al. Age and multimorbidity predict death among COVID-19 patients: results of the SARS-RAS study of the Italian society of hypertension: Results of the SARS-RAS study of the Italian society of hypertension. Hypertension 2020;76(2):366-72.

[31] Huang S, Wang J, Liu F, et al. COVID-19 patients with hypertension have more severe disease: a multicenter retrospective observational study. Hypertens Res 2020;43(8):824-31.

[32] Grasselli G, Zangrillo A, Zanella A, et al. Baseline characteristics and outcomes of 1591 patients infected with SARS-CoV-2 admitted to ICUs of the Lombardy region, Italy. JAMA 2020;323(16):1574-81.
[33] Richardson S, Hirsch JS, Narasimhan M, et al. Presenting characteristics, comorbidities, and outcomes among 5700 patients hospitalized with COVID-19 in the New York City area. JAMA 2020;323(20):2052-9.

[34] Shibata S, Arima H, Asayama K, et al. Hypertension and related diseases in the era of COVID-19: a report from the Japanese Society of Hypertension Task Force on COVID-19. Hypertens Res 2020;43(10):1028-46.

[35] Pinedo-Torres I, Flores-Fernández M, Yovera-Aldana M, et al. Prevalence of diabetes mellitus and its associated unfavorable outcomes in patients with acute respiratory syndromes due to coronaviruses infection: a systematic review and meta-analysis. Clin Med Insights Endocrinol Diabetes 2020;13:1179551420962495.

[36] Luo L, Fu M, Li Y, et al. The potential association between common comorbidities and severity and mortality of coronavirus disease 2019: a pooled analysis. Clin Cardiol 2020;43(12):1478-93.

[37] Shoar S, Hosseini F, Naderan M, et al. Meta-analysis of cardiovascular events and related biomarkers comparing survivors versus non-survivors in patients with COVID-19. Am J Cardiol 2020;135:50-61.

[38] Wang L, He W, Yu X, et al. Coronavirus disease 2019 in elderly patients: characteristics and prognostic factors based on 4-week follow-up. J Infect 2020;80(6):639-45.

[39] Chen X, Hu W, Ling J, et al. Hypertension and diabetes delay the viral clearance in COVID-19 patients. MedRxiv 2020.

[40] Abdi A, Jalilian M, Sarbarzeh PA, et al. Diabetes and COVID-19: A systematic review on the current evidences. Diabetes Res Clin Pract 2020;166:108347.

[41] Alqahtani JS, Oyelade T, Aldhahir AM, et al. Prevalence, severity and mortality associated with COPD and smoking in patients with COVID-19: a rapid systematic review and meta-analysis. PLoS One 2020;15(5):e0233147.

[42] Flick H, Arns BM, Bolitschek J, et al. Management of patients with SARS-CoV-2 infections and of patients with chronic lung diseases during the COVID-19 pandemic (as of 9 May 2020): Statement of the Austrian Society of Pneumology (ASP). Wien Klin Wochenschr 2020;132(1314):365-86. 